\title{
Russiske imperium
}

Kåre Johan Mjør

Oslo: Cappelen Damm Akademisk 2017

356 sider: ISBN 9788202548926

Omtalt av Jens Petter Nielsen [professor, Institutt for arkeologi, historie, religionsvitenskap og teologi, UIT Norges arktiske universitet, jens.petter.nielsen@uit.no]

Imperiet ble et sentralt tema i forskningen om russisk historie etter at Andreas Kappeler i 1992 utgav sitt banebrytende verk Russland als Vielvölkerreich: Entstehung, Geschichte, Zerfall. I årene som fulgte kan man tale om en vending $\mathrm{i}$ faget der man $\mathrm{i}$ økende grad forsøkte å forstå Russlands historie som et imperiums historie, i motsetning til den mer tradisjonelle fremstilling av landets historie, der den russiske staten (helt siden Karamzin) har stått i fokus. Det er en begivenhet at vi nå har fått en bok på nynorsk om Det russiske imperiets historie, skrevet at Kåre Johan Mjør, forsker ved Centrum för Rysslandstudiet ved Uppsala Universitet.

Kåre Johan Mjør tar som sitt utgangspunkt et utsagn av den britiske historikeren Geoffrey Hosking: «Storbritannia hadde eit imperium, men Russland var eit imperium og er det kan henda framleis». I Russland var imperiet en forlengelse av landet selv og ikke adskilt fra det, slik tilfellet var med Storbritannia, som hadde koloniene på den andre siden av havet. Russland var et landimperium, slik som Det osmanske imperiet og Habsburg-imperiet. Men det går snart opp for leseren at boka ikke handler om Det russiske imperiet, men om russiske imperier i flertall, ikke mindre enn fem: Det første kaller forfatteren et "ortodoks imperium» (1550-1700), det vil si Moskva-Russland fra Ivan den grusomme eller erobringen av det tatariske Kazan-khanatet i 1552, til Den store nordiske krig. Erobringen av Kazan ble begynnelsen på den prosessen som førte til at Russland ble et imperium.

Det neste imperiet, som startet med Peter den stores regjeringstid, kaller Mjør et «europeisk imperium»(1700-1850). Det var i denne perioden at tsaren, ved avslutningen av Den store nordiske krig (1721), lot seg utrope til keiser, og Russland ble opphøyd til imperium og fikk det godkjent av de europeiske maktene. Det «europeiske imperiet» ble rundt midten av 1800-tallet avløst av det Mjør kaller et russisk «nasjonalt imperium»(1850-1917), en periode med voksende russisk nasjonalisme da St. Petersburg forsøkte å feste grepet om imperiets utkanter. Så gikk dette russiske imperiet under i 1917, men ikke lenge etter oppstod det «sovjetiske imperiet»(1922-1991), som faller sammen med Sovjetunionens eksistensperiode. Mjør kaller det «Eit imperium av nasjonar», en selvmotsigelse som likevel ikke er det. Og han går videre og tar også utfordringen fra Hosking: om ikke Russland kanskje 
er et imperium fremdeles i dag. Mjør undersøker denne tesen til slutt i boka under overskriften "Eit postsovjetisk imperium» (1993-2016).

For å få dette til må forfatteren legge til grunn et bredt begrep om imperium: Det handler om store stater som giennom historien har vært ekspansive og følgelig har kommet til å omfatte forskjellige folkegrupper og områder. Et imperium har alltid et sentrum og en periferi, og periferien er klart underordnet sentret. Karakteristisk er også at imperiet styrer sine territorier på ulike måter, og de skiller seg dermed på en grunnleggende måte fra nasjonalstaten, som med sitt krav om homogenisering synes å forme en stat som forsvarer én kultur og ett språk. Innenfor rammen av imperiet må ulike kulturer og språk kunne sameksistere, og det er typisk at periferien blir styrt gjennom et samarbeid mellom sentralmakten og lokale eliter som makten delegeres til.

Denne alliansen med lokale eliter ble tynnslitt mot slutten av den perioden Mjør har kalt "det nasjonale imperiet», da den russiske staten, under trykket av den fremvoksende tyske stormakt og en økende russisk nasjonalisme, prøvde å giøre Russland mer enhetlig ved å avskaffe ulike særordninger i de vestlige grenseområdene og knytte dem fastere til Russland. Polen var det første offeret, deretter kom de baltiske guvernementene og Finland. Finland står frem som et godt eksempel på hva «russifiseringen» i denne perioden innebar. Landet fikk etter den russiske erobringen i 1808-1809 beholde sin svenske statsforfatning og fikk status som en autonom stat innenfor Det russiske imperiet med tsaren som storfyrste. Men fra slutten av århundret ble Finland utsatt for økende russifisering. Et vendepunkt var Februarmanifestet, utstedt under generalguvernør Bobrikov i 1899. I hans periode som generalguvernør ble det vedtatt en rekke lover vedrørende Finland, som avskaffet storfyrstedømmets væpnede styrker, innførte russisk språk i offentlig saksbehandling i Finland og slo fast at fellesimperiale lover, som også berørte Finland, samt lokale finske lover som berørte hele imperiets interesser nå kunne vedtas ved ensidig russisk lovgivning. På denne måten ble balansen mellom sentrum og periferi forrykket, og russiske myndigheter kunne ikke lenger basere seg på lojalitet fra de lokale eliter, som mente at Finland ikke var en del av den russiske staten, selv om det tilhørte Det russiske imperiet.

I ettertid er det lett å se at disse og andre tiltak for å styrke Russland var kontraproduktive, det vil si at de fremkalte motstand og styrket de sentrifugale kreftene i stedet for å få den motsatte effekt. I 1917 bidro denne uroen til revolusjonen, som til slutt brakte bolsjevikene til makten i Russland. Det var Lenin og Folkekommissærenes råd som i desember 1917 godkjente Finlands uavhengighet, noe som var helt i samsvar med bolsjevikenes nasjonalitetspolitikk. Lenin var overbevist om at innrømmelse av en slik rett til å bryte ut, ville skape tillit og et ønske om å forbli innenfor rammene av et nytt Russland. Det langsiktige målet var et sosialistisk fellesskap; det kunne ikke nås ved å avskaffe nasjonalismen, men ved å redusere den til en kulturell nasjonalisme. Minoritetenes kultur skulle være "nasjonal i form», men «sosialistisk i innhold». Et viktig redskap i dette arbeidet var korenizatsija, eller 
«styrkingen av den innfødte kulturen» blant etniske og nasjonale grupper på 1920og 1930-tallet. De ble alle knyttet til bestemte territorier, med unntak av russerne selv:Yuri Slezkine har metaforisk sammenlignet denne politikken med den sovjetiske kommunale leilighet, der hver familie (dvs. hver nasjonale gruppe) hadde sitt eget rom, mens bad og kjøkken var felles. Unntaket var russerne, som ikke hadde noe eget rom, men måtte holde til på badet, på kjøkkenet og i gangene.

Selv om Putin ikke bruker ordet imperium om det postsovjetiske Russland, argumenterer Kåre Johan Mjør for at det er gode grunner til å betrakte også dagens Russland som et imperium. Han viser til den russiske 1993-grunnlovens definisjon av det russiske, eller rettere "russlandske folk» (rossijskij narod) som et multietnisk folk og ikke som en nasjon i vanlig forstand. Imperiet lever videre i den føderative ordningen med nasjonale territorier og rettigheter. Den russiske føderasjonen er fremdeles et konglomerat av etniske og geografiske områder, og betegnende nok er ingen områder definert som etnisk russiske: «Russland er basert på eit etnonasjonalt prinsipp for alle andre nasjonar enn den russiske», skriver Mjør, "noko som gjer at landet strevar med å utvikle seg til ein nasjon og i staden er eit imperium, eller i alle fall ein rest av det, i form av en asymmetrisk føderasjon» (s. 272-273).

Denne imperiale fortida viser seg også i Russlands strev for å beholde eller gjenvinne sin innflytelse i det postsovjetiske rom og etablere seg i det minste som en regional stormakt. «Russland er framleis eit imperium i kraft av den heterogene strukturen sin, som i seinare tid har blitt kombinert med ein ny trong til ekspansjon i ulike former - det vera seg ved hjelp av 'mjuk' makt som skal sikra 'geopolitisk innverknad', eller fysisk og militært», skriver Mjør (s. 270). Det er også betegnende at nye områder som blir knyttet til det postsovjetiske Russland, får en særegen status. Det gjelder Krim, som først ble anerkjent som et uavhengig område, og siden innlemmet som en republikk i Den russiske føderasjonen. Sevastopol ble en "føderal by» på samme måte som Moskva og St. Petersburg er føderale byer. Sør-Ossetia og Abkhazia, som ved russisk hjelp har revet seg løs fra Georgia, vil kanskje senere bli tatt opp i Den russiske føderasjon. Søkelyset er nå på utbryterrepublikkene Donetsk og Luhansk i Donbas, som har erklært seg uavhengige av Ukraina. Det er uvisst hvilket forhold de vil få til Russland i fremtiden.

Russiske imperium er en rik bok som er vanskelig å yte rettferdighet $\mathrm{i}$ en kort anmeldelse. Mjør behandler et vanskelig og sammensatt spørsmål på en analytisk og beundringsverdig velordnet måte, og han viser at han er oppdatert på den store internasjonale litteraturen om russisk historie og om Russlands ulike periferier i vest, $\mathrm{i} ø$ øt og i sør. I det hele tatt er Russiske imperium et imponerende verk som overbeviser leseren om at bruken av begrepet imperium på Russland, også før Peter den store og etter Nikolaj 2., er fruktbar og gir viktige nye innsikter. Statsmakten står fremdeles sentralt i fremstillingen hos Kåre Johan Mjør, men det desentrerte perspektivet hans gir et mer nyansert bilde av russisk historie og kultur. Her er det ikke bare snakk om undertrykkelse og dominans fra sentrum, men også om impulser fra utkantene mot sentrum, som av den grunn også endrer seg i takt med utvidelsen 


\section{6 | JENS PETTER NIELSEN}

av imperiet. I Russland, slår Mjør fast, har sivilisering vært en gjensidig prosess mellom sentrum og periferi, og det er vanskelig å tenke seg russisk kultur uten imperiet. Som eksempler viser han blant annet til Pusjkin og Tolstojs Kaukasus-litteratur, og til komponisten Aleksandr Borodins orkesterstykke «På steppene i Sentral-Asia», der denne sønnen til en georgisk adelsmann skaper «russisk orientalisme i tonar». «Det finst ikkje noko Russland utan Orienten - Orienten er ein 'konstituerande andre' som Russland er avhengig av for å vera eit imperium, for å vera Russland» (s. 22). 